\title{
INCORPORATION OF OSTEOBLASTS (MG63) INTO 3D NANOFIBRE MATRICES BY SIMULTANEOUS ELECTROSPINNING AND SPRAYING IN BONE TISSUE ENGINEERING
}

\author{
J.R.J. Paletta ${ }^{1}$, , F. Mack ${ }^{1}$, H. Schenderlein ${ }^{2}$, C. Theisen ${ }^{1}$, J. Schmitt ${ }^{1}$, J.H. Wendorff ${ }^{2}$, \\ S. Agarwal' ${ }^{2}$, S. Fuchs-Winkelmann ${ }^{1}$ and M.D. Schofer ${ }^{1}$ \\ ${ }^{1}$ Department of Orthopedics, University of Marburg, D-35043 Marburg, Germany \\ ${ }^{2}$ Department of Chemistry, University of Marburg, D-35032 Marburg, Germany
}

\begin{abstract}
Nanofibre scaffolds are suitable tools for bone tissue engineering. Mimicking the extracellular matrix, they allow for cell growth and differentiation. However, in large 3D scaffolds, uniform cell colonisation presents an unsolved problem. Our aim was to design and analyse a method of colonising nanofibre scaffolds, combining electrospinning of fibres and electrospraying of cells, to determine its impact on cell survival, growth, and gene expression. The osteoblast-like cell line MG63 was suspended in medium and electrosprayed into growing scaffolds of poly-(l-lactic acid) (PLLA) or PLLA/Col-I blend nanofibres. Fluorescein diacetate (FDA) staining was used to determine survival and growth over a $22 \mathrm{~d}$ culture period. Expression of osteocalcin (OC) and type I collagen (Col-I) genes was determined by real time PCR. Fluorescence microscopy was used to analyse Col-I and OC deposition, as well as cell densities. While spraying distance and cell density in the spraying solution influenced survival and cell density, the combination of electrospinning and electrospraying did not negatively influence the maintenance of the osteoblast phenotype. Furthermore, VEGF induction in response to hypoxia was not suppressed, but modulated by polymer composition. Therefore, simultaneous electrospinning and electrospraying is a suitable tool in producing nanofibre based 3D cell seeded scaffolds.
\end{abstract}

Keywords: Electrospinning, electrospraying, 3D nanofibre matrices, osteoblasts, gene expression, bone tissue engineering.

\footnotetext{
*Address for correspondence:

Jürgen R.J. Paletta

Department of Orthopedics, University of Marburg

Baldingerstrasse, D-35043 Marburg, Germany
}

Telephone Number: ++49 64215863788

FAX Number: ++49 64215867007

E-mail:paletta@med.uni-marburg.de

\section{Introduction}

The reconstruction of large bony defects after injury or resection often requires bone grafting. Besides autologous or allogene bone grafts, artificial scaffolds of synthetic biomaterials (e.g. metals, polymers, porous ceramics, hydroxyapatite, collagen sponges, or hydrogels) have been developed (Shin et al., 2005; Silva et al., 2007; Agarwal et al., 2008; Glowacki and Mizuno, 2008; Khan et al., 2008; Kneser et al., 2006; Roberts et al., 2008). Nanofibre scaffolds, or nanoscaffolds, offer great advantages (Zhang et al., 2005; Ashammakhi et al., 2008) and can be produced by a broad spectrum of biocompatible and biodegradable polymers (e.g. polyglycolic acid, poly-(l-lactic acid), poly- $\varepsilon$-caprolactone, polyurethanes, polyphosphazenes, collagen, gelatin and chitosan) as well as copolymers from the corresponding monomers in various compositions (Liao et al., 2006; Greiner and Wendorff, 2007). A broad spectrum of nanofibre-based scaffolds can therefore be produced, with different mechanical and biophysical properties. This can be accomplished by self-assembly (Berndt et al., 1995; Yu et al., 1996; Fields et al., 1998; Hartgerink et al., 2001), thermally induced liquid - liquid phase separation for the formation of nanofibrous foam materials (Zhang and Ma, 2000; Zhang and Ma, 2002) or carbon dioxide laser supersonic drawing (Suzuki and Aoki, 2008) and electrospinning (Reneker et al., 2000; Hohman et al., 2001; Moses et al., 2001; Shin et al., 2001; Yarin et al., 2001; Feng, 2002; Feng, 2003; Fridrikh et al., 2003; Li, 2004; Subbiah, 2005). Nanofibres are thought to mimic the extracellular matrix ( $\mathrm{Li}$ et al., 2002; Liao et al., 2006; Woo et al., 2007) and allow growth and differentiation of human mesenchymal stem cells (hMSCs) towards osteoblasts (Badami et al., 2006; Schofer et al., 2008), especially after functionalisation with collagen or growth factors (Schofer et al., 2008). Thus, nanoscaffolds represent a suitable matrix for bone tissue engineering.

However, colonisation of a desired scaffold with cells and subsequent cellular processes including migration, proliferation and differentiation of cells within the scaffold play an important role. It has been shown earlier that a high number of initially seeded cells can improve structural stability and biochemical composition of engineered tissues (Vunjak-Novakovic et al., 1998a; Carrier et al., 1999). In case of tendon repair the seeding density also increased the rate and extent of contraction (Hani et al., 2000). On the other hand, low seeding density promotes fibrous growth of cells (Temenoff and Mikos, 2000). Furthermore, uniform cell spatial distribution in the tissue 
scaffold is desirable for normal function and phenotypic expression of regenerated tissues (Langer, 2000).

Thus far, static seeding has been the most prevalent seeding method used in tissue culture (Susan et al., 1997; Aigner et al., 1998; Rachel et al., 2000). Several new methods, including dynamic mixing (Vunjak-Novakovic et al., 1998b), agitation (Kim et al., 1998; Burg et al., 2000), filtration seeding (Li et al., 2001), and a perfusion flowseeding process (Kim et al., 2000) have been developed to improve cellularity and cell distribution in the cell-polymer construct by inducing relative flow between the suspended cells and polymer scaffolds.

Although these methods revealed cell densities comparable to native bone $\left(5 \times 10^{8}\right.$ cells $\left./ \mathrm{cm}^{2}\right)$ (Muschler et al., 1997), in the case of nanofibre scaffolds, the use of these methods is limited due to pore size and structure (Stankus et al., 2006). Sacrificial co-fibres can be incorporated into the nanofibre scaffold, which boost pore sizes and facilitate cell migration (Baker et al., 2008; Guimaraes et al., 2010). Furthermore, the variation of fibre diameter results in a variation of pore size (Pham et al., 2006). Alternatively pores can be introduced by salt particles that are subsequently leached out (Nam et al., 2007), ice crystals (Simonet et al., 2007), or photopatterning (Sundararaghavan et al., 2010). These manipulations of the nanofibre scaffold influence the mechanical properties, especially after removal of sacrificial co-fibres, and do not circumvent cell seeding .

A direct incorporation of living cells into nanoscaffolds during electrospinning could be a promising approach for producing cell-containing scaffolds. One possibility is the combination of electrospraying with electrospinning, a process which was described for cardiovascular tissue engineering (Stankus et al., 2007). However, for bone tissue engineering, little is known about the influence of this method on osteoblast gene expression. Therefore, we aimed to (1) develop a method combining electrospinning and electrospraying of osteoblast-like cells; and (2) to determine the impact of this process on survival, growth, and expression of genes associated with osteoblast lineage and formation of the extracellular matrix.

In cell-seeded scaffolds, vascular supply represents the major problem. The lack of a functional microvasculature connected to the host blood supply is the culprit for implant failure (Santos and Reis, 2010). Angiogenesis and vascular endothelial growth factor (VEGF) as its main regulator play a critical role. In hypoxic conditions, VEGF expression is upregulated by Hif stabilisation, inducing proliferation and migration of endothelial cells by activation of tyrosine kinase receptors VEGFR 1 and 2 and resulting in neoangiogenesis (Ferrara, 1999a; Ferrara, 1999b; Ferrara, 2000a; Ferrara, 2000b; Ferrara, 2001; Ferrara and Gerber, 2001; Ferrara et al., 2003).

It is paramount that the incorporation of cells into nanoscaffolds is not affected by either the electrospraying itself, or the nanofibre construct. For this reason, we also analysed the impact of this method on VEGF expression as the main regulator of angiogenesis.

\section{Materials and Methods}

\section{MG63 cell culture}

MG63 cells (ATCC: CRL-1427) were incubated with Dulbecco's Modified Eagle Medium (DMEM) with glucose and glutamine (PAA, Linz, Austria), supplemented with $10 \%$ foetal calf serum (Stem Cell Technologies, Vancouver, Canada) and 1\% penicillin/streptomycin, at 37 ${ }^{\circ} \mathrm{C}$ in a $5 \% \mathrm{CO}_{2}$ humidified atmosphere. Cell-containing nanoscaffolds were placed in Petri dishes and cultured over a $22 \mathrm{~d}$ period as previously described (Paletta et al., 2009), under growth (DMEM + 10\% FCS + 1\% penicillin/ streptomycin) or osteoinductive conditions according to Jaiswal et al. (1997). Here, standard medium was replaced by medium containing $0.1 \mu \mathrm{M}$ dexamethasone, $0.05 \mathrm{mM}$ ascorbic acid-2-phosphate, and $10 \mathrm{mM} ß$-glycerophosphate (Sigma, Taufkirchen, Germany).

\section{Construction of cell-containing nanofibre scaffolds}

In order to incorporate cells into nanoscaffolds, a parallel approach combining electrospinning of polymer and electrospraying of cells was used. The polymer solution was electrospun at a distance of $11 \mathrm{~cm}$, using a flow rate of $0.76 \mathrm{~mL} / \mathrm{h}$, and with an applied voltage of $20-30 \mathrm{kV}$. For preparation of poly-(1-lactic acid) (PLLA) nanofibres by electrospinning, a 4\% (weight/weight) PLLA solution (molecular weight 220,000 g/mol, (Bras et al., 2008) (Resomer L210, Boehringer Ingelheim Germany) in dichloromethane (DCM) was prepared by stirring overnight at room temperature until a homogenous solution was obtained. In order to functionalise PLLA with type I collagen, PLLA and type I collagen were dissolved in hexafluoroisopropanol (HFIP) in the desired ratio until a $4.5 \%$ (weight/volume) polymer solution was made (Schofer et al., 2009).

Voltage ranging from $0-30 \mathrm{kV}$ for the electrode, and 0 or $5 \mathrm{kV}$ for the counter electrode were investigated, with a constant cell density of $2 \times 10^{6}$ cells $/ \mathrm{mL}$ and a needle distance of $11 \mathrm{~cm}$. Needle distances of 6 versus $11 \mathrm{~cm}$, under $20 \mathrm{kV}$ and a cell suspension of $2 \times 10^{6}$ cells $/ \mathrm{mL}$, were tested. In order to investigate the cell density of the spraying solution on viability, variations between $0.25-2$ x $10^{6}$ cells $/ \mathrm{mL}$ were used $(20 \mathrm{kV} ; 6 \mathrm{~cm})$.

Cells containing nanoscaffolds were collected on 18 $\mathrm{mm}$ cover slips, and placed on a rotating counter electrode under aseptic conditions. The thickness of the PLLAnanoscaffolds varied between 30-60 $\mu \mathrm{m}$ while the thickness of the PLLA-Collagen scaffolds ranged between 70-130 $\mu \mathrm{m}$ depending on the torque limited micrometer gauge, which slightly compressed the scaffold. The duration of each series of experiments was 4-5 h, resulting in 22-25 cover slips. Since 3D scaffolds last approximately $4 \mathrm{~h}$, we determined survival rates under conditions occurring in the electrospinning apparatus. Cells were placed on cover slips, left in the apparatus at room temperature for $4 \mathrm{~h}$, and moistened with medium as necessary.

\section{Histological analysis}

Vital staining was performed with $30 \mu \mathrm{g} / \mathrm{mL}$ phosphate buffered fluorescein diacetate (FDA) (Sigma-Aldrich, 
Munich, Germany) and $38 \mu \mathrm{g} / \mathrm{mL}$ ethidium bromide (Sigma-Aldrich) in phosphate buffered saline (PBS). Analysis was performed with a Leica (Wetzlar, Germany) DM5000 fluorescence microscope.

For scanning electron microscopy, samples were fixed in $2.5 \%$ glutaraldehyde in cacodylate buffer $(0.1 \mathrm{~mol} / \mathrm{L}$, $\mathrm{pH} 7.2$ ) for $24 \mathrm{~h}$ at $4{ }^{\circ} \mathrm{C}$, post fixed with $1 \% \mathrm{OsO}_{4}$ and dehydrated in serial solutions of ethanol (60-100\%) for $15 \mathrm{~min}$, followed by a second soak in $100 \%$ ethanol. Each specimen underwent carbon dioxide critical point drying and was sputter coated with platinum before examination with a scanning electron microscope (Jeol, Tokyo, Japan; JSM-7500F) at an accelerating voltage of $4 \mathrm{kV}$ in the lower secondary electron (LEI) mode. Fibre diameter was similarly analysed and interpreted with Image $J^{\circledR}(\mathrm{NIH}$, Bethesda, MD, USA) software. 100 diameters for both PLLA and PLLA-Col-I-blend were counted.

For light microscopy analysis, cell scaffolds were fixed with $4 \%$ formalin dehydrated in serial solutions of ethanol (60-100\% for $15 \mathrm{~min}$ each) and paraffin embedded. $5 \mu \mathrm{m}$ sections were stained with a Masson Goldner Kit (Merck, Darmstadt, Germany) according to the manufacturer's instructions.

Van Kossa staining was performed using 1\% aqueous silver nitrate solution for $1 \mathrm{~h}$ followed by several washing steps in distilled water and incubation in 5\% sodium thiosulphate for $5 \mathrm{~min}$. Alizarin red staining was performed (2 g/100 mL, pH 4.1-4.3).

\section{Gene expression analysis}

RNA was extracted from cell layers at days 4, 10 and 22 (under osteoinductive conditions) using an RNeasy Mini Kit (Qiagen GmbH, Hilden, Germany) according to the manufacturer's instructions, and quantified spectrometrically. Starting from $1 \mu \mathrm{g}$ RNA, $20 \mu \mathrm{L}$ of cDNA were synthesised using Omniscript reverse transcriptase and oligo-dT primer in the presence of dNTP (Qiagen). Quantitative RT-PCR reactions were performed and monitored using the Mastercycler ${ }^{\circledR}$ ep realplex Detection System (Eppendorf, Hamburg, Germany) and RealMaster Mix CyberGreen (Eppendorf). Genes of interest were analysed in cDNA samples ( $5 \mu \mathrm{L}, 50 \mu \mathrm{L} /$ reaction) using the $\Delta \Delta C T$ method (Livak and Schmittgen, 2001) and CyberGreen. Purity of the single PCR products was verified by melting point analysis.

Primers for type I collagen (forward: C A G C C G C T T C A C C T A C A G C, reverse : TTTTGTATTCAATCACTGTCTTGCC), osteocalcin (forward: GAAGCCCAGCGGTGCA, reverse: CACTACCTCGCTgCCCTCC), VEGF (forward: ATCT TCAAGCCATCCTGTGTGC, reverse: T GCGCT T G T CA CAT T T T T T T G), В MP-2 (forward: AACACTGTGCGCAGGTTCC, reverse: CTCCGGGTTGTTTTCCCAC) and Hif-1A (forward: CGTTCCTTCGATCAGTTGTC, reverse: TCAGTGGTGGCAGTGGTAGT) were used (TIB Biomol, Berlin, Germany). The applied VEGF primer pair included the most common splice variants (VEGF-121, 145, 148, 165, 183 and 189; (Zygalaki et al., 2005). We used $1 \%$ agarose gel electrophoresis to determine which splice variants were amplified.

\section{Immunofluorescence microscopy}

Samples obtained at day 22 were fixed in acetone and methanol (methanol $>99.5 \%$, for $5 \mathrm{~min}$ at $-20{ }^{\circ} \mathrm{C}$ followed by acetone $>99 \%$ for 1 and $5 \mathrm{~min}$ at $-20^{\circ} \mathrm{C}$ ), washed three times with PBS and exposed to blocking buffer ( $1 \%$ donkey serum albumin PBS) for $30 \mathrm{~min}$ at room temperature in order to minimise non-specific absorption of antibodies. After a second wash, cells were incubated with primary antibodies against Col-I (Abcam, Ab6308, Cambridge, UK) and OC (Acris, BP710, Hiddenhausen, Germany).

Visualisation was done after PBS washing using cy-2- or cy-3-conjugated secondary antibodies (Dianova, Hamburg, Germany) at room temperature for $1 \mathrm{~h}$. The slices were stained with DAPI and embedded in mounting medium (Fluoromount-G, Southern Biotechnology, Birmingham, AL, USA). Fluorescence microscopy was done using a Leica DM5000. Microphotographs of at least three different areas were obtained at a primary magnification of 20x high power field (HPF). Intensity of fluorescence was determined using Quips analysis software. Total cell count of DAPI-stained nuclei were obtained. The series of experiments were analysed by independent observers. The level of hypoxia was detected using a hypoxyprobe-1 staining kit (HPI Inc., Middlesex Turnpike Burlington, MA; USA) according to the manufacturer's instructions.

\section{Statistical analysis}

All values were expressed as the mean \pm standard error of the mean (SEM) of at least 3 different independent assays and compared using the Mann-Whitney U test, Student's $t$-test, or ANOVA with Bonferroni as a post-hoc test depending on data distribution. A $p$-value of less than 0.05 was considered to be statistically significant.

\section{Results}

\section{Influence of electrospraying on survival of osteoblast- like cell line MG63}

Voltage had no influence on cell survival during the electrospraying process (Fig. 1A). However, survival significantly decreased when high electrode distances were used during the entire process (Fig. 1C). The density of cells incorporated in the PLLA/Col-I nanofibre scaffolds by electrospraying was dependent on cell concentration (Fig. 1B). Fig. 1 D gives an impression of the FDA staining used for evaluation.

In order to simulate the effect of duration of the process on cell survival cells were placed directly in the spinning apparatus and moistened if necessary. Over a period of 4 $\mathrm{h}$ there was an increase of dead cells from $3-5 \%(\mathrm{t}=0 \mathrm{~h})$ to $9-41 \%(t=4 \mathrm{~h})$. The great variance in the results may have been due to unequal drying. In order to determine the effects of solvent residues, we used polymer films produced from DCM or HFIP. Of the controls, $8-12 \%$ of cells died after $4 \mathrm{~h}$. On HFIP films, $1-25 \%$ of cells died, whereas on DCM films 9-57\% of cells died within $4 \mathrm{~h}$. This effect was not found to be statistically significant as compared to corresponding control without polymer. 

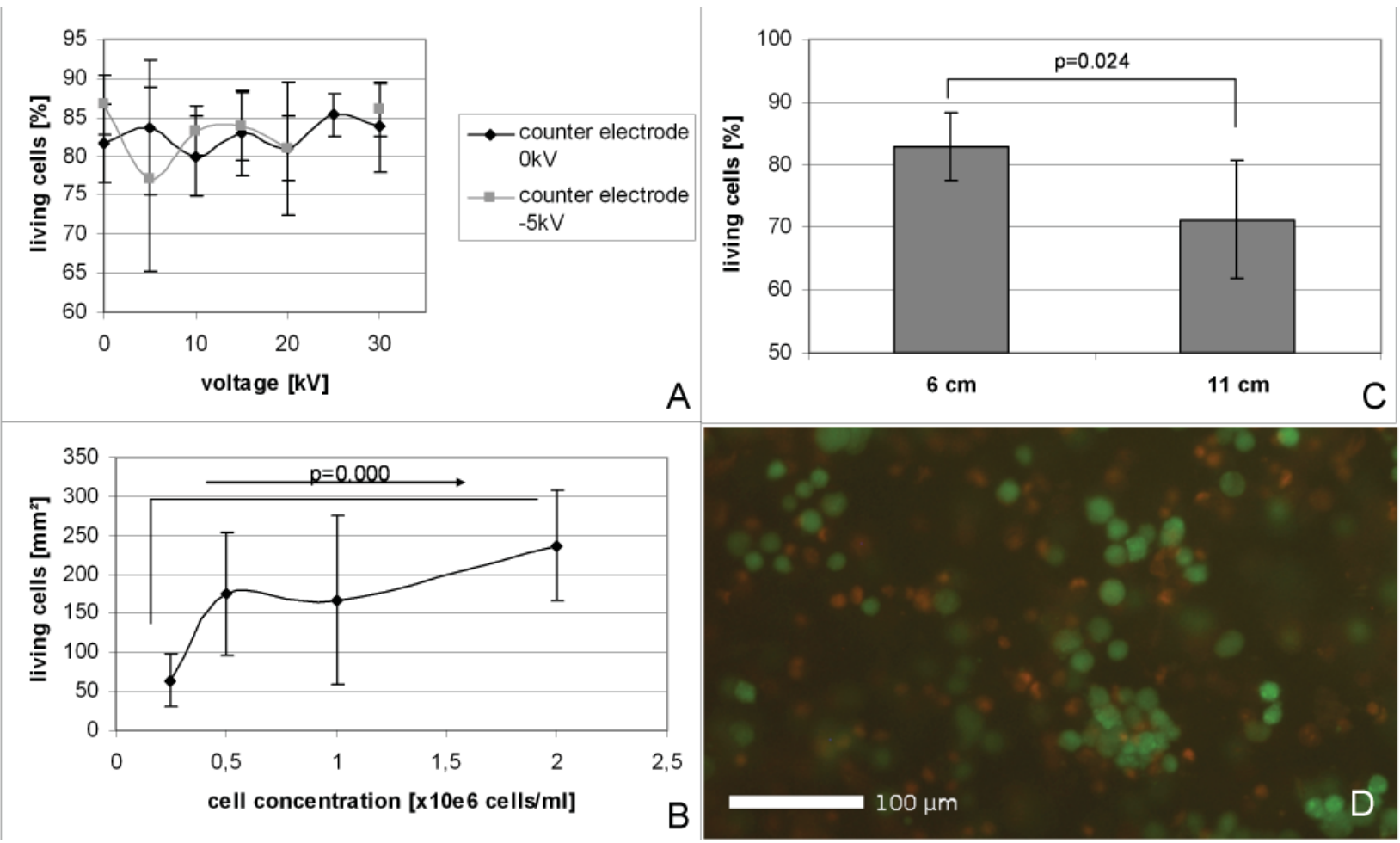

Fig. 1: Influence of electrospraying parameters on survival of osteoblast-like cell line MG63. Influence of voltage (electrospraying) (A), cell density in suspension (electrospraying combined with electrospinning of PLLA/Col-I) (B) and spraying distance (electrospraying) (C) on the survival of osteoblasts as determined using FDA staining (D).

\section{Influence of electrospraying on nanofibre morphology}

PLLA nanofibres had a mean diameter of $1324 \pm 1204$ $\mathrm{nm}$ with a porous surface and spindle sharp beats when electrospinning was combined with electrospraying (Fig. 2A). On the other hand, PLLA/Col-I blend nanofibres had a smooth surface with a mean diameter of $319 \pm 123$ nm (Fig. 2B).

\section{Survival and growth of osteoblast-like cell line MG63 incorporated in nanofibre scaffolds}

The number of living cells by FDA staining varied between $335-525$ cells $/ \mathrm{mm}^{2}$ within the scaffold, representing initial survival rates of $55-66 \%$, independent of the polymer used. Round cells elongated within $4 \mathrm{~d}$ (Fig. 3A, D). After $22 \mathrm{~d}$, the scaffolds were completely covered with cells (Fig. 3B, E). Cross-sections of paraffin embedded scaffolds demonstrated that the osteoblasts were distributed throughout the PLLA and the PLLA/Col-I blend scaffolds. However, there was a difference in distribution; in PLLA/ Col-I blend nanoscaffolds the cells were arranged in layers (Fig. 3F), while in PLLA nanoscaffolds, cells were distributed more randomly (Fig. 3C).

Fig. 2: Influence of coaxial electrospinning on nanofiber morphology. SEM micro photographs of PLLA (A) and PLLA/Col-I (B) nanofibre surfaces produced by a combination of electrospraying and electrospinning. Scaffolds were washed with distilled water in order to remove salts and debris.

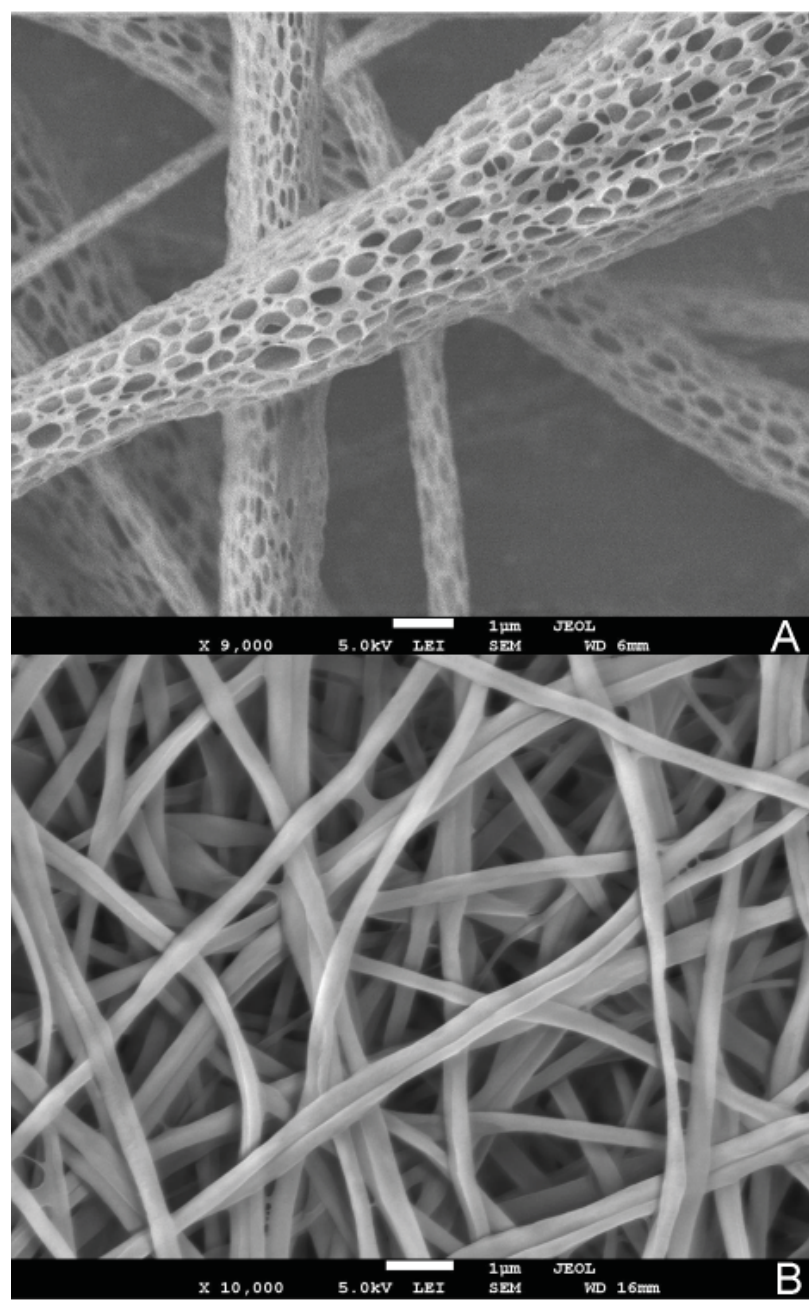




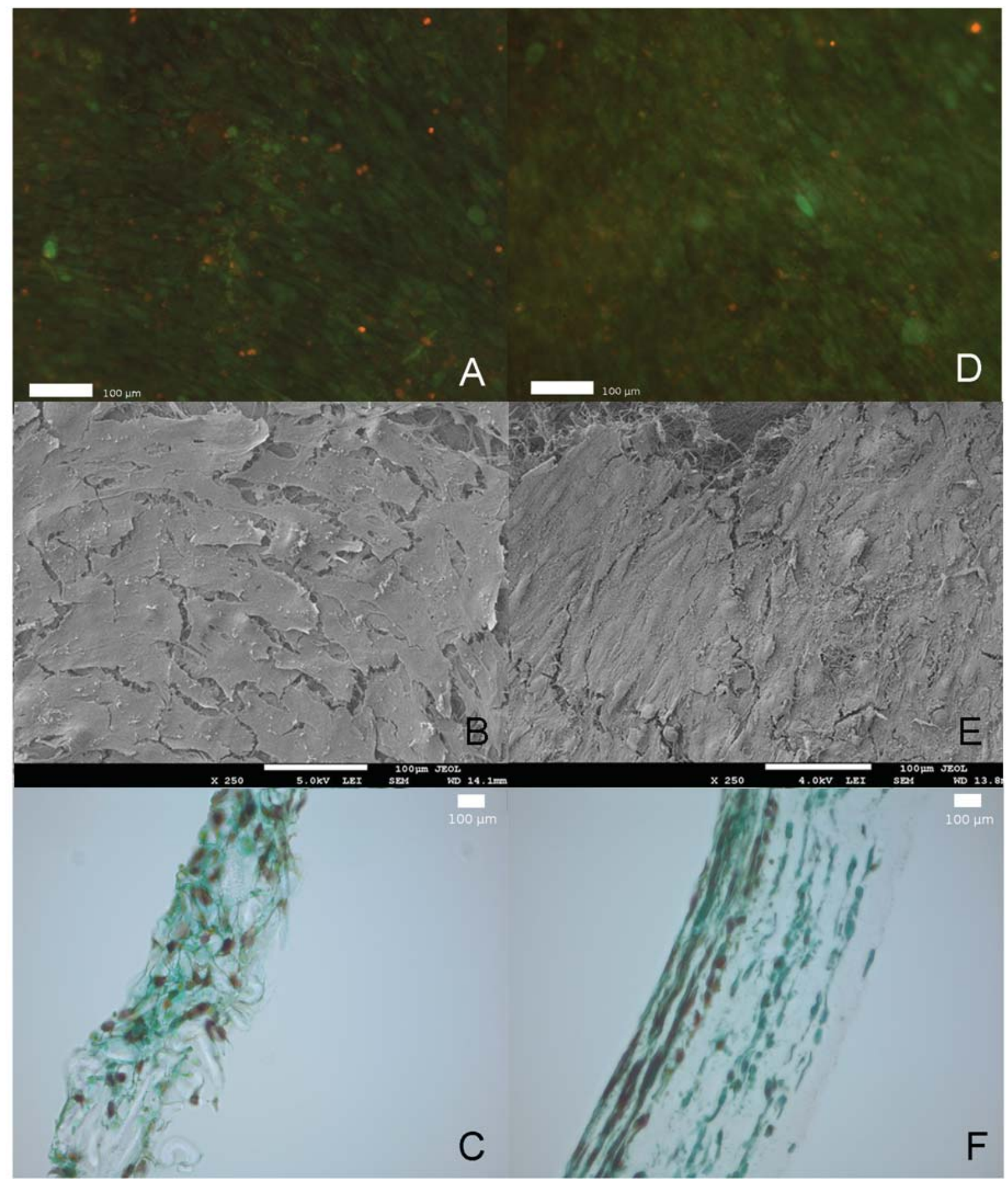

Fig. 3: Survival and growth of osteoblast-like cell line MG63 incorporated in nanofibre scaffolds. FDA staining of MG63 cultured in PLLA (A) or PLLA/Col-I (D) nanofibre scaffolds after $4 \mathrm{~d}$ of incubation. SEM analysis of the scaffold surface of MG63 cultured in PLLA (B) or PLLA/Col-I (E) nanofibre scaffolds after $22 \mathrm{~d}$ of incubation. Cross-sections of paraffin embedded cell-containing PLLA (C) and PLLA/Col-I scaffolds (F) after $22 \mathrm{~d}$ of incubation

\section{Influence of the 3D scaffolds on the maintenance of osteoblast-like phenotype: gene expression and deposition of Col-I and OC}

After cells were incorporated into PLLA nanoscaffolds and cultured over a $22 \mathrm{~d}$ period, we found a slight increase in collagen gene expression in the early stages (Fig. 4 A), followed by an increase in Col-I immunostaining by $22 \mathrm{~d}$ (Fig. 4 C, E, F). OC gene expression remained unaffected (Fig. 4 B). However, there was an increase in immunostaining for OC (Fig. 4 D, E, F) and calcium incorporation could be demonstrated by both van Kossa and alizarin red staining (Fig. G).

When PLLA/Col-I scaffolds were used in experiments over a $22 \mathrm{~d}$ period, there was an increase in Col-I (Fig. 5 C, E, F) and OC (Fig. 5 D, E, F) immunostaining as 

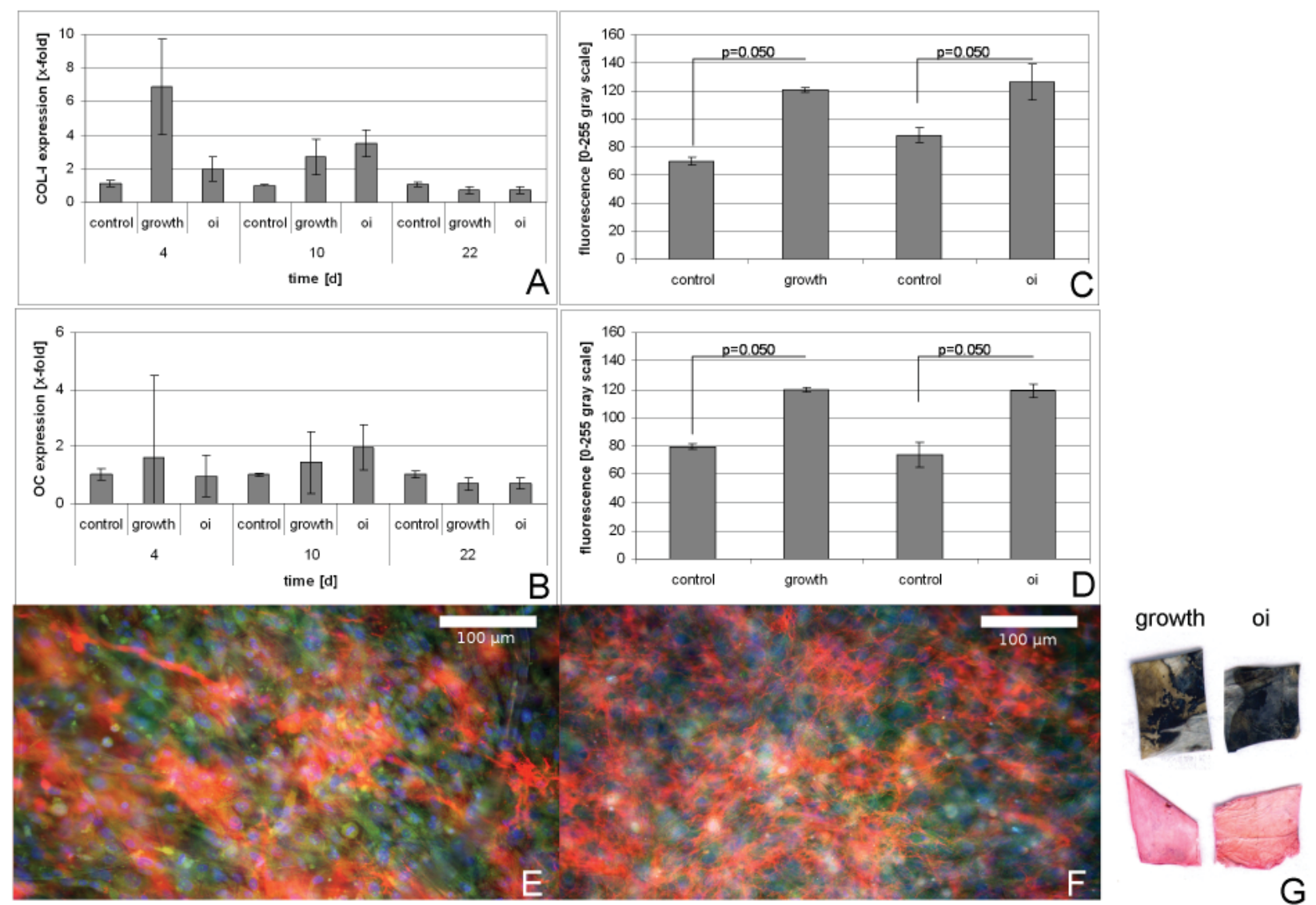

Fig. 4: Maintaining of osteoblast-like phenotype of cells incorporated into PLLA nanofibre scaffolds by electrospraying. Time course of Col-I gene expression (A) as determined by qPCR and deposition (C, E growth, F oi) as determined by immunofluorescence (red). Time course of OC gene expression (B) as determined by qPCR and deposition (D, E growth, F oi) as determined by immunofluorescence (green). G van Kossa and alizarin red staining after $22 \mathrm{~d}$ (growth=growth condition; oi=osteoinductive condition).

compared to cover slip control. Gene expression of both genes remained constant (Fig. 5 A, B). Furthermore, calcium deposition was detected after 22 d using van Kossa or alizarin red staining (Fig. $5 \mathrm{G}$ ).

In order to characterise the maintenance of the osteoblast phenotype, we further analysed BMP-2 gene expression when incorporated into the desired scaffold (Figure 6). Independent of the kind of scaffold, there was an initial increase in BMP-2 gene expression during the initial stage of culture. In the case of PLLA nanoscaffolds, the increase was more dominant compared to PLLA/Col-I nanoscaffolds (Fig. 6 B).

\section{Influence of 3D scaffolds on VEGF expression and splice variants}

In the osteoblast-like cell line MG63, VEGF was upregulated after $4 \mathrm{~d}$, when incorporated into PLLA nanoscaffolds (Fig. 7 A). At this point, hypoxia was detected within the scaffolds (Fig. 7D, E). In addition, a greater than 10-fold increase in Hif-1a gene expression was detected (data not shown). VEGF upregulation was restricted to the splice variant 121 on agarose gel electrophoresis (Fig. $7 \mathrm{C}$, lane C, P). Over time, the expression pattern changed. VEGF121, VEGF165, and VEGF189 were found after 10 and $22 \mathrm{~d}$, independent of culture conditions. VEGF expression was significantly lower in the PLLA/Col-I nanoscaffolds (Fig.
7 B), as compared to the PLLA nanoscaffolds. VEGF121 and the splice variants VEGF165 and VEGF189 were detected during the initial stages of culture (Fig. 7 C, lane B). Although hypoxic cells were detected (Fig. 7G, H), Hif-1a gene expression was reduced to 0.4-0.2 compared to cover slip controls (data not shown).

\section{Discussion}

Scaffolds based on PLLA nanofibres are a suitable matrix for tissue engineering. Previous investigators have successfully seeded cells onto nanoscaffolds and demonstrated attachment, proliferation, differentiation, and migration (Yang et al., 2004; Boudriot et al., 2005; Yang et al., 2005; Badami et al., 2006; Boudriot et al., 2006; Li et al., 2006; Woo et al., 2007; Corey et al., 2008; Schofer et al., 2008; Theisen et al., 2010). However, cellular infiltration of thick scaffolds by conventional seeding and culture methods is time consuming and difficult. Some investigators claim that cells slowly migrate and "push" their way through nanoscale fibres in vitro (Li et al., 2002), as cells would not naturally migrate into synthetic materials (Telemeco et al., 2005; Stankus et al., 2007). In our study, the direct incorporation of cells during electrospinning represents a promising method that has previously been 

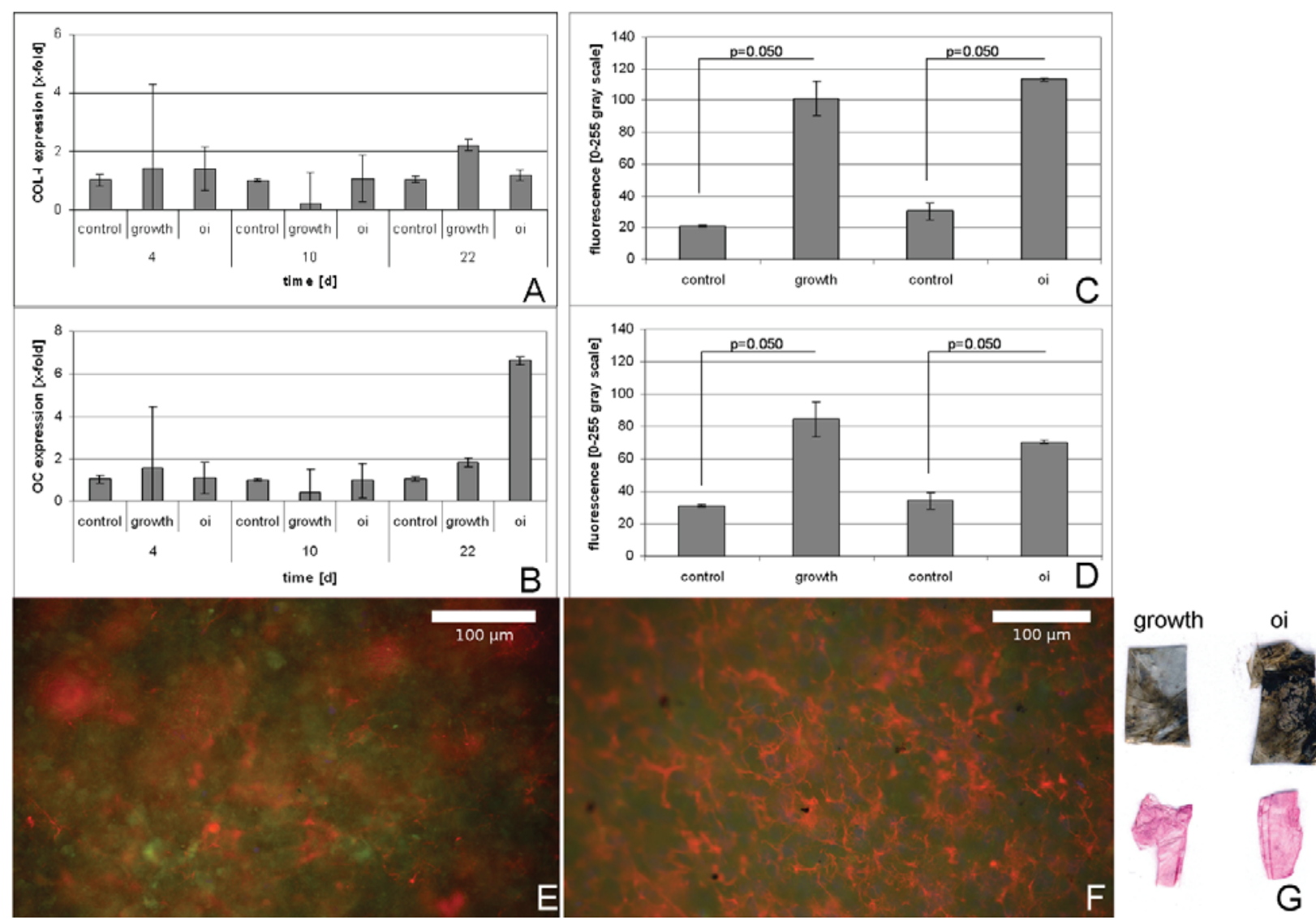

Fig. 5: Maintaining of osteoblast-like phenotype of cells incorporated into PLLA/Col-I nanofibre scaffolds by electrospraying. Time course of Col-I gene expression (A) as determined by qPCR and deposition (C, E growth, F oi) as determined by immunofluorescence (red). Time course of OC gene expression (B) as determined by qPCR and deposition (D, E growth, F oi) as determined by immunofluorescence (green). G van Kossa and alizarin red staining after $22 \mathrm{~d}$ (growth=growth condition; oi=osteoinductive condition).

used with water soluble polymers (van Aalst et al., 2008). This approach is not useful when using PLLA nanofibres because of the requirement for organic solvents. Therefore, we combined PLLA nanofibre electrospinning onto the DCM scaffold and the electrospinning of PLLA/ Col-I blend nanofibre onto the HFIP scaffold with electrospraying, in order to design cell seeded scaffolds for bone tissue engineering.

The combination of these parallel electrospinning processes had no influence on the nanofibre surface, as compared to earlier studies (Schofer et al., 2008; Paletta et al., 2009; Schofer et al., 2009) although the diameter of PLLA nanofibres electrospun from DCM tended to vary more. Importantly, synthetic nanofibres may exhibit properties comparable to natural collagen fibres, thus serving as a superior scaffolding versus solid walled architecture for promoting osteoblast differentiation and biomineralisation (Woo et al., 2007).

With respect to electrospraying, Jurkat cells (Suwan et al., 2006), smooth muscle cells (Stankus et al., 2006; Stankus et al., 2007), or human astrocytoma cells (Jayasinghe and Townsend-Nicholson, 2006) survive the process and are not affected by high electrical voltage.

However, our data indicate that the process itself affects survival of osteoblast-like cells. In particular, the spraying distance used during scaffold construction impacted the
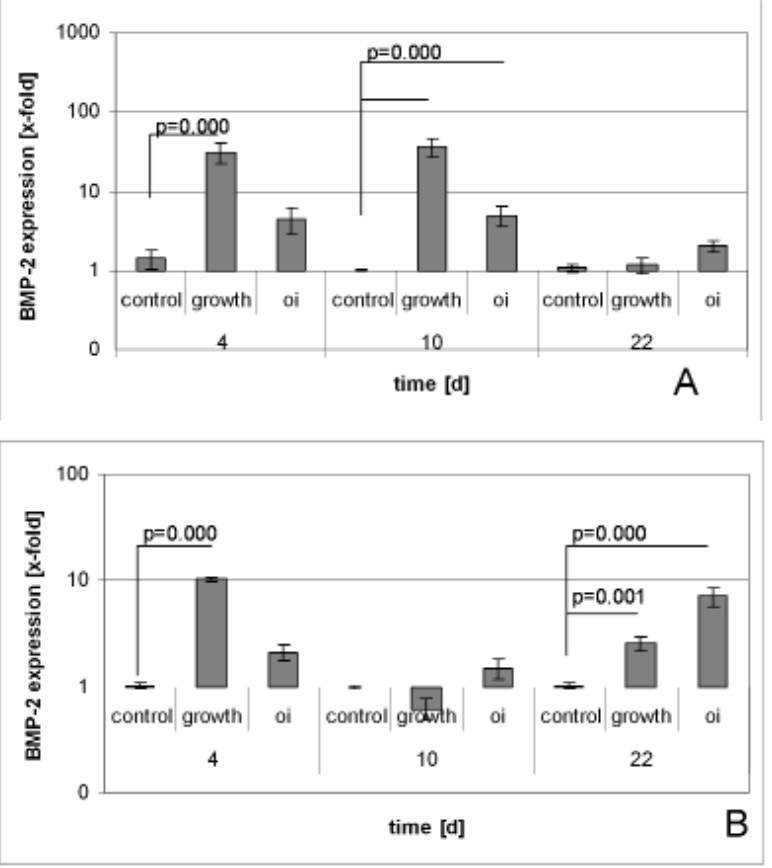

Fig. 6: BMP-2 gene expression of MG63 incorporated in 3-dimensional scaffolds. Time course of BMP-2 gene expression of cells incorporated into PLLA(A) or PLLA/ Col-I (B) nanofibre scaffolds. 

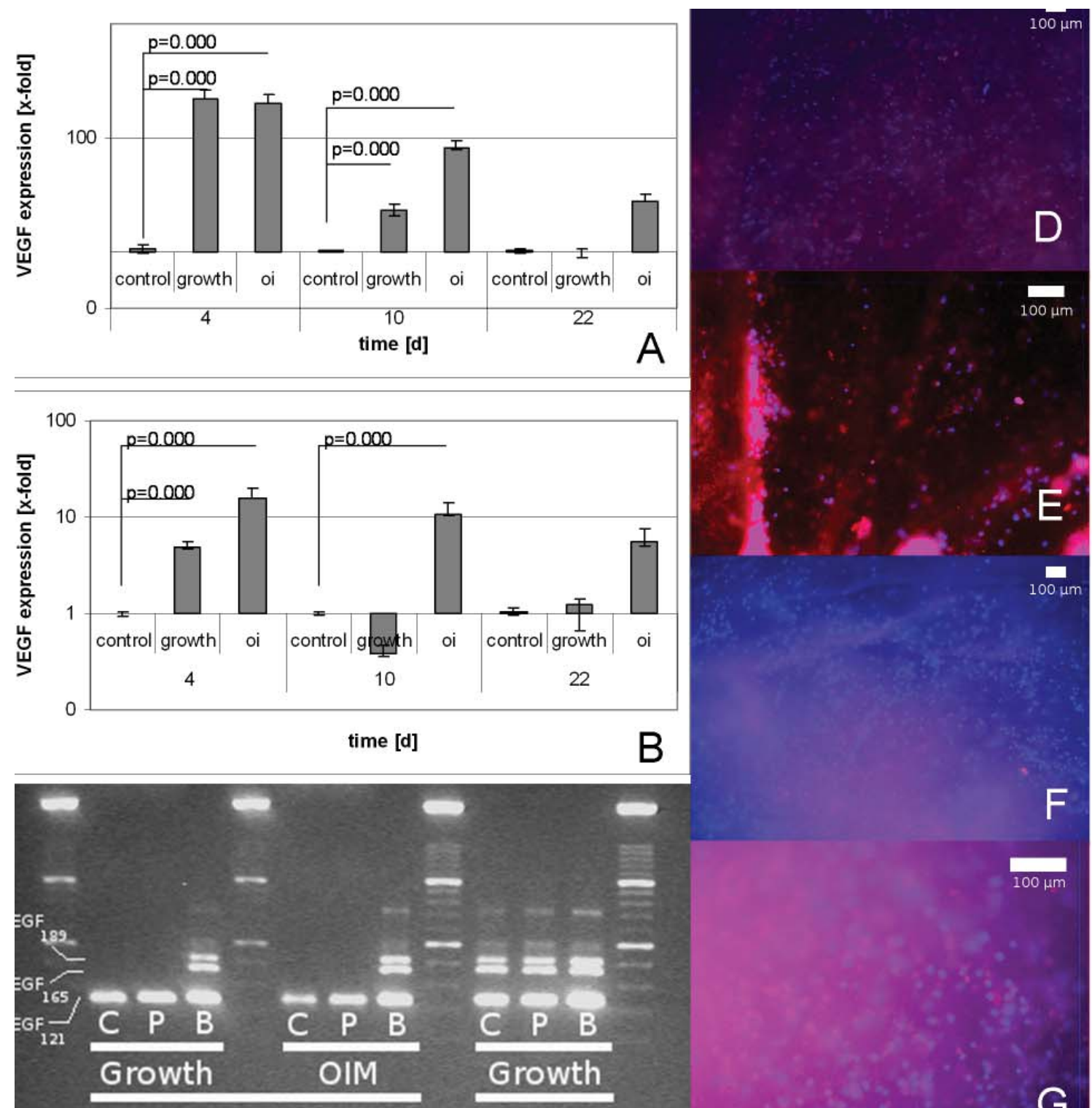

DAY 4

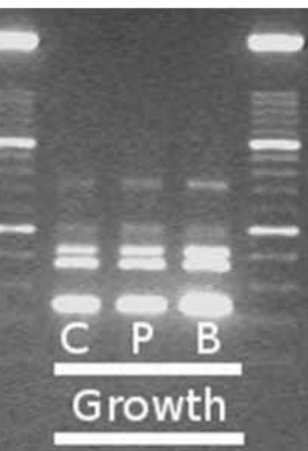

DAY 10

G

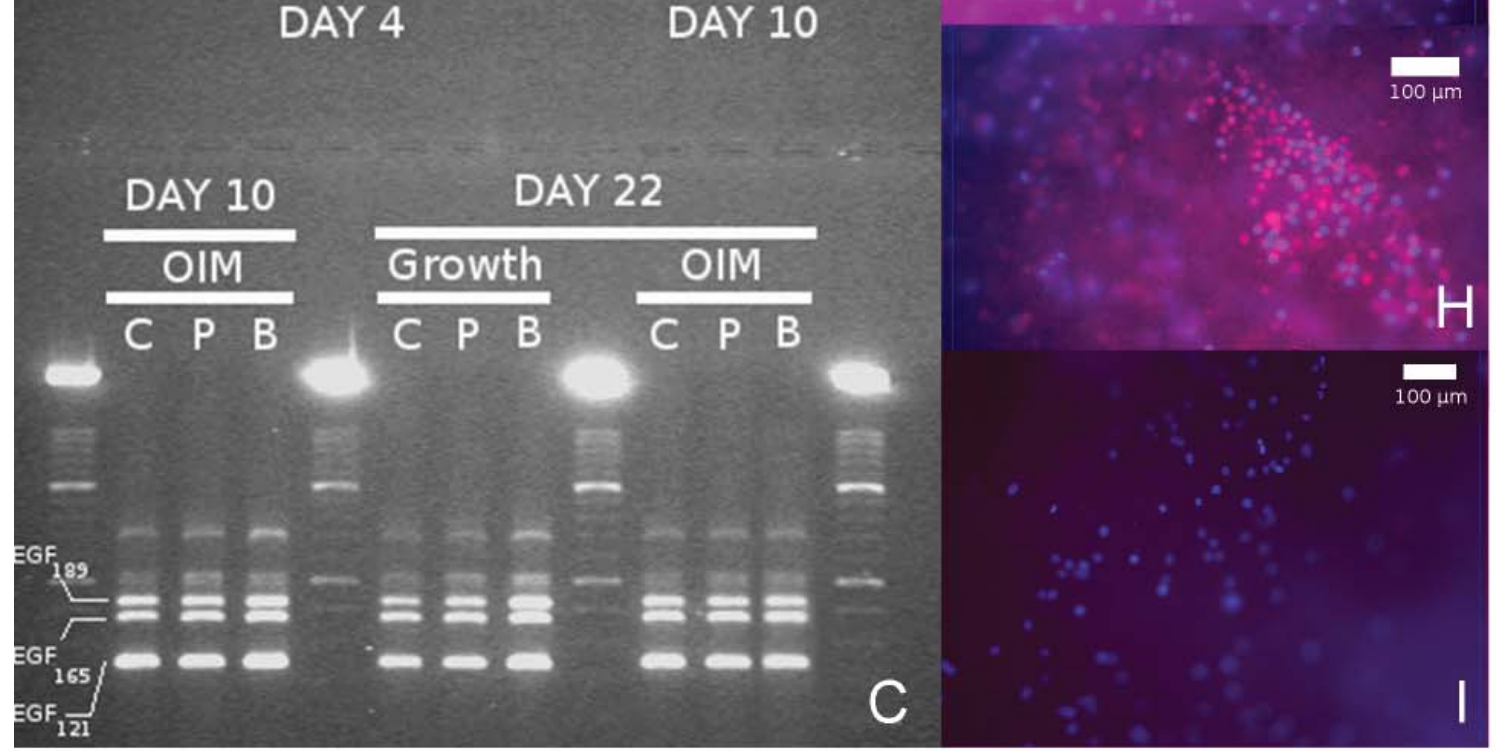

Fig. 7: Influence of the 3-dimensional cell containing nanofibre scaffolds on angiogenesis. Time course of VEGF gene expression of MG63 cells cultured in PLLA (A) or PLLA/Col-I (B) nanofibre scaffolds. Agarose gel electrophoresis of the $\mathrm{PCR}$ products $(\mathrm{C}) . \mathrm{C}=$ control, $\mathrm{P}=\mathrm{PLLA}, \mathrm{B}=\mathrm{PLLA} / \mathrm{Col}-\mathrm{I}, \mathrm{OIM}=$ osteoinductive conditions. D-I Fluorescence microscopy demonstrating hypoxic cells in PLLA scaffolds under growth (D) and osteoinductive conditions (E) as well as in PLLA/Collagen scaffolds under growth $(\mathrm{G})$ and osteoinductive conditions (H). F, I negative controls. 
initial cell densities of seeded scaffolds. One explanation is that a greater distance leads to higher evaporation rates of cell-containing droplets, resulting in an increased salt concentration and therefore decreased cell survival. In addition, the duration for scaffold construction appears to be critical for cell survival. Survival was increased when cells were electrosprayed alone, versus simultaneously with electrospinning (80-90\% vs. 55-66\%). Electrospraying alone was accomplished in only 5 min while combined electrospraying and electrospinning lasted for 4-5 h. In fact, when cells were left in the spinning apparatus on cover slips, the number of dead cells increased. By influencing the environmental conditions in the spinning apparatus, cell survival might be increased.

We cannot exclude the fact that DCM residues in the polymer may affect survival due to the increased number of apoptotic cells in the experiments. Although this effect was not significant, the choice of solvent for fibre preparation should made carefully, as the solvent used for fibre preparation in PLLA influences the mechanical properties of the scaffold and the fibre structure (Paletta et al., 2009).

We demonstrated that after incorporation into the scaffold, cell growth was observed over the $22 \mathrm{~d}$ period with an equal distribution of cells within the scaffolds. Nevertheless, one limitation of the study may have been the use of an immortalised cell line, MG63, as different cell types appear to differ in sensitivity to the electrospinning process (van Aalst et al., 2008). Thus, comparisons with other studies should be made.

In bone tissue engineering, besides cell growth and survival, extracellular matrix formation by electrosprayed cells is important. There was no evidence that Col-I or OC gene expression was downregulated after electrospraying. Moreover, fluorescent microscopy demonstrated increased type I collagen, osteocalcin, and calcium deposition in the two different nanofibre matrices, indicating that the nanoscaffolds might facilitate bone formation when seeded with cells.

Furthermore, BMP-2 expression by cells incorporated into nanoscaffolds by electrospraying was upregulated, indicating that the osteoblast phenotype was not affected. BMP-2 is a well known differentiation factor which belongs to the TGF- $\beta$ superfamily (Yamaguchi et al., 2000; Balint et al., 2003; Canalis et al., 2003; Wan and Cao, 2005; Wu et al., 2007). Polymer composition of the scaffolds seemed to influence BMP-2 gene expression, which was reduced in PLLA/type I collagen nanofibres. The reason for this was not analysed in detail, but we speculate that cross-talk in the collagen-integrin-focal adherence kinase and BMP-Smad signalling as previously described is involved (Suzawa et al., 1999; Suzawa et al., 2002; Xiao et al., 2002). Furthermore, the influence of topology cannot be excluded, as described in macrophages (Takebe et al., 2003).

Another important factor in bone tissue engineering is hypoxia, which is associated with a diffusion limitation in the cell seeded scaffold. In our study, after incorporation into a 3D nanoscaffold, hypoxia occurred in scaffolds thinner than expected by diffusion limitation. Whether this is triggered by boosted metabolic activity of the MG63 cell line is unclear. However, VEGF was consequently upregulated, especially in the PLLA nanofibre scaffold where the process appears to be triggered by Hif-1a upregulation and elicited by hypoxia. Therefore the electrospraying process does not interfere with VEGF expression and angiogenesis. Transferring this information to other cell types, scaffold functionalisation using VEGF should not be necessary. We would expect scaffold vascularisation to occur immediately after implantation.

The PLLA/collagen blend used for nanofibre production appears to influence the process. Although hypoxic cells were detected within scaffolds, Hif-1a expression was not enhanced and VEGF expression was lower as compared to PLLA scaffolds. In addition, during the initial growth period cells produced bigger splice variants of VEGF (165, 189) with heparin binding sites that may interact with the extracellular matrix, resulting in limited diffusion of growth factor. Therefore, scaffold composition may have a notable impact on angiogenesis.

\section{Conclusion}

Parallel electrospinning and spraying is a suitable method for the construction of 3D nanoscaffolds continuously seeded with cells.

Critical parameters influencing survival and distribution of cells here are the electrode distance used for cell spraying, the duration of fabrication and to some extend the solvent and polymer used for fibre fabrication. Beyond that no negative influence could be detected on gene expression or matrix formation. Provided that these results can be transferred to primary cells like hMSCs or osteoblasts when incorporated into nanofibre scaffolds by electrospraying, it will be interesting to know whether such scaffolds will enhance bone healing in vivo.

\section{Acknowledgments}

This study was supported by the Deutsche Forschungsgemeinschaft (German Research Foundation), Grant No. BO 3065/1-1.

\section{References}

Agarwal S, Wendorff JH, Greiner A (2008) Use of electrospinning technique for biomedical applications. Polymer 49: 5603-5621.

Aigner J, Tegeler J, Hutzler P, Campoccia D, Pavesio A, Hammer C, Kastenbauer E, Naumann A (1998) Cartilage tissue engineering with novel nonwoven structured biomaterial based on hyaluronic acid benzyl ester. J Biomed Mater Res 42: 172-181.

Ashammakhi N, Ndreu A, Yang Y, Ylikauppila H, Nikkola L (2008) Nanofiber-based scaffolds for tissue engineering. Eur J Plast Surg Online First.

Badami AS, Kreke MR, Thompson MS, Riffle JS, Goldstein AS (2006) Effect of fiber diameter on spreading, 
proliferation, and differentiation of osteoblastic cells on electrospun poly(lactic acid) substrates. Biomaterials 27: 596-606.

Baker BM, Gee AO, Metter RB, Nathan AS, Marklein RA, Burdick JA, Mauck RL (2008) The potential to improve cell infiltration in composite fiber-aligned electrospun scaffolds by the selective removal of sacrificial fibers. Biomaterials 29: 2348-2358.

Balint E, Lapointe D, Drissi H, van der Meijden C, Young DW, van Wijnen AJ, Stein JL, Stein GS, Lian JB (2003) Phenotype discovery by gene expression profiling: Mapping of biological processes linked to BMP-2mediated osteoblast differentiation. J Cell Biochem 89: 401-426.

Berndt P, Fields GB, Tirrell M (1995) Synthetic lipidation of peptides and amino acids: Monolayer structure and properties. J Am Chem Soc 117: 9515-9522.

Boudriot U, Dersch R, Greiner A, Wendorff JH (2006) Electrospinning approaches toward scaffold engineering - a brief overview. Artif Organs 30: 785-792.

Boudriot U, Goetz B, Dersch R, Greiner A, Wendorff HJ (2005) Role of electrospun nanofibers in stem cell technologies and tissue engineering. Macromol Symp 225: 9-16.

Bras AR, Malik P, Dionisio M, Mano JF (2008) Influence of crystallinity in molecular motions of poly(L-lactic acid) investigated by dielectric relaxation spectroscopy. Macromolecules 41: 6419-6430.

Burg KJL, W. D. Holder J, Culberson CR, Beiler RJ, Greene KG, Loebsack AB, Roland WD, Eiselt P, Mooney DJ, Halberstadt CR (2000) Comparative study of seeding methods for three-dimensional polymeric scaffolds. J Biomed Mater 51: 642-649.

Canalis E, Economides AN, Gazzerro E (2003) Bone morphogenetic proteins, their antagonists, and the skeleton. Endocr Rev 24: 218-235.

Carrier RL, Papadaki M, Rupnick M, Schoen FJ, Bursac N, Langer R, Freed LE, Vunjak-Novakovic G (1999) Cardiac tissue engineering: Cell seeding, cultivation parameters, and tissue construct characterization. Biotechnol Bioeng 64: 580-589.

Corey JM, Gertz CC, Wang BS, Birrell LK, Johnson SL, Martin DC, Feldman EL (2008) The design of electrospun PLLA nanofiber scaffolds compatible with serum-free growth of primary motor and sensory neurons. Acta Biomater. 4: 863-875.

Feng JJ (2003) Stretching of a straight electrically charged viscoelastic jet. J Non-Newton Fluid Mech 116: 55-70.

Feng JJ (2002) The stretching of an electrified nonNewtonian jet: A model for electrospinning. Phys Fluids 14: 3912-3926.

Ferrara N (1999a) Molecular and biological properties of vascular endothelial growth factor. J Mol Med 77: 527 543.

Ferrara N (2001) Role of vascular endothelial growth factor in regulation of physiological angiogenesis. Am J Physiol Cell Physiol 280: C1358-1366.

Ferrara N (1999b) Role of vascular endothelial growth factor in the regulation of angiogenesis. Kidney Int 56: 794-814.
Ferrara N (2000a) Vascular endothelial growth factor and the regulation of angiogenesis. Recent Progr Hormone Res 55: 15-35.

Ferrara N (2000b) VEGF: An update on biological and therapeutic aspects. Curr Opin Biotechnol 11: 617-624.

Ferrara N, Gerber HP (2001) The role of vascular endothelial growth factor in angiogenesis. Acta Haematol 106: $148-156$.

Ferrara N, Gerber HP, LeCouter J (2003) The biology of VEGF and its receptors. Nat Med 9: 669-676.

Fields GB, Lauer JL, Dori Y, Forns P, Yu Y-C, Tirrell M (1998) Proteinlike molecular architecture: Biomaterial applications for inducing cellular receptor binding and signal transduction. Peptide Sci 47: 143-151.

Fridrikh SV, Yu JH, Brenner MP, Rutledge GC (2003) Controlling the fiber diameter during electrospinning. Phys Rev Lett 90: 144502.

Glowacki J, Mizuno S (2008) Collagen scaffolds for tissue engineering. Biopolymers 89: 338-344.

Greiner A, Wendorff JH (2007) Electrospinning: A fascinating method for the preparation of ultrathin fibres. Angew Chemie Int Ed 46: 5670-5703.

Guimaraes A, Martins A, Pinho ED, Faria S, Reis RL, Neves NM (2010) Solving cell infiltration limitations of electrospun nanofiber meshes for tissue engineering applications. Nanomedicine 5: 539-554.

Hani AA, David LB, Matthew TH, Rania EI, Ying W, Randell GY, Sudha K, Gregory PB (2000) In vitro characterization of mesenchymal stem cell-seeded collagen scaffolds for tendon repair: Effects of initial seeding density on contraction kinetics. J Biomed Mater Res 51: 233-240.

Hartgerink JD, Beniash E, Stupp SI (2001) Selfassembly and mineralization of peptide-amphiphile nanofibers. Science 294: 1684-1688.

Hohman MM, Shin M, Rutledge G, Brenner MP (2001) Electrospinning and electrically forced jets. I. Stability theory. Phys Fluids 13: 2201-2220.

Jaiswal N, Haynesworth SE, Caplan AI, Bruder SP (1997) Osteogenic differentiation of purified, cultureexpanded human mesenchymal stem cells in vitro. J Cell Biochem 64: 295-312.

Jayasinghe SN, Townsend-Nicholson A (2006) Stable electric-field driven cone-jetting of concentrated biosuspensions. Lab on a Chip 6: 1086-1090.

Khan Y, Yaszemski MJ, Mikos AG, Laurencin CT (2008) Tissue engineering of bone: material and matrix considerations. J Bone Joint Surg-Am 90 Suppl 1: 36-42.

Kim B-S, Putnam AJ, Kulik TJ, Mooney DJ (1998) Optimizing seeding and culture methods to engineer smooth muscle tissue on biodegradable polymer matrices. Biotechnol Bioeng 57: 46-54.

Kim SS, Sundback CA, Kaihara S, Benvenuto MS, Kim BS, Mooney DJ, Vacanti JP (2000) Dynamic seeding and in vitro culture of hepatocytes in a flow perfusion system. Tissue Eng 6: 39-44.

Kneser U, Schaefer DJ, Polykandriotis E, Horch RE (2006) Tissue engineering of bone: The reconstructive surgeon's point of view. J Cell Mol Med 10: 7-19.

Langer R (2000) Tissue engineering. Mol Ther 1: 12-15.

Li D, Xia Y (2004) Electrospinning of nanofibers: Reinventing the wheel? Adv Mater 16: 1151-1170. 
Li WJ, Cooper JA Jr, Mauck RL, Tuan RS (2006) Fabrication and characterization of six electrospun poly(alpha-hydroxy ester)-based fibrous scaffolds for tissue engineering applications. Acta Biomater 2: 377-385.

Li WJ, Laurencin CT, Caterson EJ, Tuan RS, Ko FK (2002) Electrospun nanofibrous structure: A novel scaffold for tissue engineering. J Biomed Mater Res 60: 613-621.

Li Y, Ma T, Kniss DA, Lasky LC, Yang ST (2001) Effects of filtration seeding on cell density, spatial distribution, and proliferation in nonwoven fibrous matrices. Biotechnol Progr 17: 935-944.

Liao S, Li B, Ma Z, Wei H, Chan C, Ramakrishna S (2006) Biomimetic electrospun nanofibers for tissue regeneration. J Biomed Materials 1: R45-53.

Livak KJ, Schmittgen TD (2001) Analysis of relative gene expression data using real-time quantitative PCR and the 2(- $\left.\Delta \Delta \mathrm{C}_{\mathrm{T}}\right)$ method. Methods 25: 402-408.

Moses MH, Michael S, Gregory R, Michael PB (2001) Electrospinning and electrically forced jets. II. Applications. Phys Fluids 13: 2221-2236.

Muschler GF, Boehm C, Easley K (1997) Aspiration to obtain osteoblast progenitor cells from human bone marrow: The influence of aspiration volume. J Bone Joint Surg Am 79: 1699-1709.

Nam J, Huang Y, Agarwal S, Lannutti J (2007) Improved cellular infiltration in electrospun fiber via engineered porosity. Tissue Eng 13: 2249-2257.

Paletta J, Erffmeier K, Theisen C, Hussain D, Wendorff JH, Greiner A, Fuchs-Winkelmann S, Schofer MD (2009) Influence of poly-(L-lactic acid) nanofiber functionalization on maximum load, Young's modulus, and strain of nanofiber scaffolds before and after cultivation of osteoblasts: An in vitro study. ScientificWorldJournal 9: 1382-1393.

Pham QP, Sharma U, Mikos AG (2006) Electrospun poly( $\varepsilon$-caprolactone) microfiber and multilayer nanofiber/ microfiber scaffolds: Characterization of scaffolds and measurement of cellular infiltration. Biomacromolecules 7: 2796-2805.

Rachel G, Lilia S, Riad A, Jose CM, Smadar C (2000) Hepatocyte behavior within three-dimensional porous alginate scaffolds. Biotechnol Bioeng 67: 344-353.

Reneker DH, Yarin AL, Fong H, Koombhongse S (2000) Bending instability of electrically charged liquid jets of polymer solutions in electrospinning. J Appl Phys 87: 4531-4547.

Roberts SJ, Howard D, Buttery LD, Shakesheff KM (2008) Clinical applications of musculoskeletal tissue engineering. Br Med Bull 86: 7-22.

Santos MI, Reis RL (2010) Vascularization in bone tissue engineering: Physiology, current strategies, major hurdles and future challenges. Macromol Biosci 10: 12-27.

Schofer MD, Boudriot U, Leifeld I, Sutterlin RI, Rudisile M, Wendorff JH, Greiner A, Paletta JR, FuchsWinkelmann S (2009) Characterization of a PLLAcollagen I blend nanofiber scaffold with respect to growth and osteogenic differentiation of human mesenchymal stem cells. ScientificWorldJournal 9: 118-129.

Schofer MD, Fuchs-Winkelmann S, Gräbedünkel C, Wack C, Dersch R, Rudisile M, Wendorff JH, Greiner A, Paletta JRJ, Boudriot U (2008) Influence of poly(L-lactic acid) nanofibers and BMP-2-containing poly(L-lactic acid) nanofibers on growth and osteogenic differentiation of human mesenchymal stem cells. ScientificWorldJournal 8: 1269-1279.

Shin H, Temenoff JS, Bowden GC, Zygourakis K, Farach-Carson MC, Yaszemski MJ, Mikos AG (2005) Osteogenic differentiation of rat bone marrow stromal cells cultured on Arg-Gly-Asp modified hydrogels without dexamethasone and beta-glycerol phosphate. Biomaterials 26: 3645-3654.

Shin YM, Hohman MM, Brenner MP, Rutledge GC (2001) Electrospinning: A whipping fluid jet generates submicron polymer fibers. Applied Phys Lett78: 11491151.

Silva GA, Coutinho OP, Ducheyne P, Reis RL (2007) Materials in particulate form for tissue engineering. 2. Applications in bone. J Tissue Eng Regen Med 1: 97-109.

Simonet M, Schneider OD, Neuenschwander P, Stark WJ (2007) Ultraporous 3D polymer meshes by low-temperature electrospinning: Use of ice crystals as a removable void template. Polym Eng Sci 47: 2020-2026

Stankus JJ, Guan J, Fujimoto K, Wagner WR (2006) Microintegrating smooth muscle cells into a biodegradable, elastomeric fiber matrix. Biomaterials 27: 735-744.

Stankus JJ, Soletti L, Fujimoto K, Hong Y, Vorp DA, Wagner WR (2007) Fabrication of cell microintegrated blood vessel constructs through electrohydrodynamic atomization. Biomaterials 28: 2738-2746.

Subbiah T, Bhat GS, Tock RW, Parameswaran S, Ramkumar SS (2005) Electrospinning of nanofibers. J Appl Polymer Sci 96: 557-569.

Sundararaghavan HG, Metter RB, Burdick JA (2010) Electrospun fibrous scaffolds with multiscale and photopatterned porosity. Macromol Biosci 10: 265-270.

Susan LI, Genevieve MC, Michael JM, Alan WY, Michael JY, Antonios GM (1997) Bone formation by threedimensional stromal osteoblast culture in biodegradable polymer scaffolds. J Biomed Mater Res 36: 17-28.

Suwan NJ, Amer NQ, Eagles PAM (2006) Electrohydrodynamic jet processing: An advanced electricfield-driven jetting phenomenon for processing living cells. Small 2: 216-219.

Suzawa M, Takeuchi Y, Fukumoto S, Kato S, Ueno N, Miyazono K, Matsumoto T, Fujita T (1999) Extracellular matrix-associated bone morphogenetic proteins are essential for differentiation of murine osteoblastic cells in vitro. Endocrinology 140: 2125-2133.

Suzawa M, Tamura Y, Fukumoto S, Miyazono K, Fujita T, Kato S, Takeuchi Y (2002) Stimulation of Smad1 transcriptional activity by Ras-extracellular signalregulated kinase pathway: A possible mechanism for collagen-dependent osteoblastic differentiation. J Bone Miner Res 17: 240-248.

Suzuki A, Aoki K (2008) Biodegradable poly(Llactic acid) nanofiber prepared by a carbon dioxide laser supersonic drawing. Eur Polym J 44: 2499-2505.

Takebe J, Champagne CM, Offenbacher S, Ishibashi K, Cooper LF (2003) Titanium surface topography alters cell shape and modulates bone morphogenetic protein 2 Expression in the J774a.1 macrophage cell line. J Biomed Mat Res 64: 207-216. 
Telemeco TA, Ayres C, Bowlin GL, Wnek GE, Boland ED, Cohen N, Baumgarten CM, Mathews J, Simpson DG (2005) Regulation of cellular infiltration into tissue engineering scaffolds composed of submicron diameter fibrils produced by electrospinning. Acta Biomater 1: 377 385 .

Temenoff JS, Mikos AG (2000) Review: Tissue engineering for regeneration of articular cartilage. Biomaterials 21: 431-440.

Theisen C, Fuchs-Winkelmann S, Knappstein K, Efe T, Schmitt J, Paletta J, Schofer M (2010) Influence of nanofibers on growth and gene expression of human tendon derived fibroblast. Biomed Eng Online 17: 9.

Van Aalst JA, Reed CR, Han L, Andrady T, Hromadka M, Bernacki S, Kolappa K, Collins JB, Loboa EG (2008) Cellular Incorporation into electrospun nanofibers: Retained viability, proliferation, and function in fibroblasts. Ann Plas Surg 60: 577-583.

Vunjak-Novakovic G, Obradovic B, Martin I, Bursac PM, Langer R, Freed LE (1998a) Dynamic cell seeding of polymer scaffolds for cartilage tissue engineering. Biotechnology Progr 14: 193-202.

Vunjak-Novakovic G, Obradovic B, Martin I, M. Bursac PM, Langer R, Freed LE (1998b) Dynamic cell seeding of polymer scaffolds for cartilage tissue engineering. Biotechnol Progr 14: 193-202.

Wan M, Cao X (2005) Bmp Signaling in Skeletal Development. Biochem Biophys Res Comm 328: 651-657.

Woo KM, Jun J-H, Chen VJ, Seo J, Baek J-H, Ryoo H-M, Kim G-S, Somerman MJ, Ma PX (2007) Nanofibrous scaffolding promotes osteoblast differentiation and biomineralization. Biomaterials 28: 335-343.

Wu X, Shi W, Cao X (2007) Multiplicity of BMP signaling in skeletal development. Ann NY Acad Sci 1116: 29-49.

Xiao G, Gopalakrishnan R, Jiang D, Reith E, Benson MD, Franceschi RT (2002) Bone morphogenetic proteins, extracellular matrix, and mitogen-activated protein kinase signaling pathways are required for osteoblast-specific gene expression and differentiation in MC3T3-E1 cells. J Bone Miner Res 17: 101-110.

Yamaguchi A, Komori T, Suda T (2000) Regulation of osteoblast differentiation mediated by bone morphogenetic proteins, hedgehogs, and CBFA1. Endocr Rev 21: 393-411.

Yang F, Murugan R, Wang S, Ramakrishna S (2005) Electrospinning of nano/micro scale poly(L-lactic acid) aligned fibers and their potential in neural tissue engineering. Biomaterials 26: 2603-2610.

Yang F, Xu CY, Kotaki M, Wang S, Ramakrishna S (2004) Characterization of neural stem cells on electrospun poly(L-lactic acid) nanofibrous scaffold. J Biomater SciPolym Ed 15: 1483-1497.

Yarin AL, Koombhongse S, Reneker DH (2001) Taylor cone and jetting from liquid droplets in electrospinning of nanofibers. J Appl Phys 90: 4836-4846.

Yu YC, Berndt P, Tirrell M, Fields GB (1996) Selfassembling amphiphiles for construction of protein molecular architecture. J Am Chem Soc 118: 12515-12520.

Zhang R, Ma PX (2000) Synthetic nano-fibrillar extracellular matrices with predesigned macroporous architectures. J Biomed Mater Res 52: 430-438.

Zhang R, Ma PX (2002) Processing of polymer scaffolds: Phase separation. Academic Press, San Diego.

Zhang Y, Lim CT, Ramakrishna S, Huang ZM (2005) Recent development of polymer nanofibers for biomedical and biotechnological applications. J Mater Sci-Mater Med 16: 933-946.

Zygalaki E, Stathopoulou A, Kroupis C, Kaklamanis L, Kyriakides Z, Kremastinos D, Lianidou ES (2005) Realtime reverse transcription-PCR quantification of vascular endothelial growth factor splice variants. Clin Chem 51: 1518-1520.

\section{Discussion with Reviewer}

Reviewer I: Do the authors expect that they will find similar results in thicker scaffolds that must be prepared for defect filling?

Authors: Yes and no. I think it will depend on the parameters. Focusing on fibre diameter, porosity and distribution of the cells in the scaffold there will be similar results. These parameters depend on physical aspects of the electrospinning process and on the interaction of the jets. Therefore they are independent of the scaffold thickness and consequently of the spinning time. The latter could have an impact on the survival rates, at least with the spinning apparatus used in this study. Here an apparatus with control elements for temperature, $\mathrm{CO}_{2}$, atmosphere and humidity or the use of a multi jet apparatus may overcome this problem. 